\title{
Evaluation of Source Water Quality Standards for Total Coliforms, TOC, and COD in Taiwan
}

\author{
E.-E. Chang ${ }^{1}$; Pen-Chi Chiang ${ }^{2}$; Yi-Li Lin ${ }^{3}$; and Hsiang-Ping Tsai ${ }^{4}$
}

\begin{abstract}
The objective of this research is to review the current status of source water as compared with the Taiwanese source water quality standards promulgated in 1997. The total coliforms, total organic carbon (TOC) and chemical oxygen demand (COD) were selected as the major parameters for review because of their specific characteristics associated with the disinfection efficiency and disinfection by-products formation and in compliance with source water quality in Taiwan. The water treatment plant with unacceptable source water needs to improve its source water quality and establish the implementation plan based on the results of comprehensive performance evaluation. Throughout this investigation, it suggests that revisions to water quality standards be divided into two execution phases, to achieve the long-term goal of improving source water quality.
\end{abstract}

DOI: 10.1061/(ASCE)1090-025X(2005)9:3(193)

CE Database subject headings: Taiwan; Water quality; Water pollution; Organic carbons; Disinfection.

\section{Introduction}

The quality of source water in Taiwan is deteriorating rapidly due to discharges of domestic and industrial wastewaters. In addition to wastewater discharges, non-point source pollutants also play an important role to source water pollution. In order to avoid heavier source water pollution, popularize pollution-prevention program and ensure safe drinking water for public health, the Taiwan Environmental Protection Administration (Taiwan EPA) enacted the Drinking Water Management Act (DWMA), which was promulgated and became effective on November 10, 1972, and then amended on May 21, 1997. The major contents issued in this DWMA are as follows: general provisions, water source management, facility management, water quality management, penalties, and supplementary provisions.

Concern over defining standards for source water quality around the world is not only recent. In April of 1970, the Water Quality Committee of the Japanese Living Environment Council published water quality standards for water resources area to protect the source water quality as well as public health (Kiluchi 1975). In 1971, the United States Public Water Supplies Panel at the request of the U.S. Environmental Protection Agency proposed water quality criteria for source water (Van der Leeden et

${ }^{1}$ Dept. of Biochemistry, Taipei Medical Univ., $250 \mathrm{Wu}-\mathrm{Hsing} \mathrm{St}$. Taipei, Taiwan (corresponding author). E-mail: eechang@tmu.edu.tw

${ }^{2}$ Graduate Institute of Environmental Engineering, National Taiwan Univ., 71 Chou-Shan Rd., Taipei, Taiwan.

${ }^{3}$ Graduate Institute of Environmental Engineering, National Taiwan Univ., 71 Chou-Shan Rd., Taipei, Taiwan.

${ }^{4}$ Dept. of Biochemistry, Taipei Medical Univ., 250 Wu-Hsing St., Taipei, Taiwan.

Note. Discussion open until December 1, 2005. Separate discussions must be submitted for individual papers. To extend the closing date by one month, a written request must be filed with the ASCE Managing Editor. The manuscript for this paper was submitted for review and possible publication on November 2, 2004; approved on November 23, 2004. This paper is part of the Practice Periodical of Hazardous, Toxic, and Radioactive Waste Management, Vol. 9, No. 3, July 1, 2005. (OASCE, ISSN 1090-025X/2005/3-193-203/\$25.00. al. 1990). In June of 1975, the council of European Communities (EC) adopted a Council Directive for the Member States concerning the required quality of surface waters intended as sources of drinking water (EC 1975). As for the source water quality standards, criteria or guidelines adopted by countries around the world, either a uniform set of standards for all sources or various levels of standards for different source waters are formulated. For example, the United States and Australia adopted uniform standards for source water quality instead of mandatory standards to guide the water supply industry to improve drinking water quality (NAS 1972; ANZECC 2000). However, Japan, Canada, France and the EC adopted various levels of standards (Kikuchi 1995; MELP 1995; EC 1975). In Taiwan, the current regulations classify water bodies into various classifications with corresponding water quality standards.

Since source water contamination is a universal issue, it appears that enforcing mandatory source water quality standards may encounter compliance problems. Besides, seeking new drinking water sources is becoming more difficult in Taiwan so that it is important to protect the source water as well as upgrade the treatment process in response to the poor source water quality. In order to ensure the safety of treated water to consumers, both the CCP (Composite Correction Program) and CPE (Comprehensive Performance Evaluation) techniques suggested by USEPA (1998) can be used herein to provide the technical information to determine if searching for an alternative raw water source or optimizing (or upgrading) the existing water treatment is required. The CPE method is a systematic step-by-step evaluation of a facility's design capabilities and associated administrative, operational, and maintenance practices to achieve the optimum performance of the facility in an existing plant. Then, a comprehensive assessment of the facility's operation capability will be made and included in the performance-limiting factors for the selected water treatment plant. The water treatment plants in Taiwan that do not comply with the source water quality standards are requested to conduct the CPE program to evaluate the current capability of the unit treatment process, and have to develop the implementation plan as suggested by the CPE team to achieve the desired water quality. 


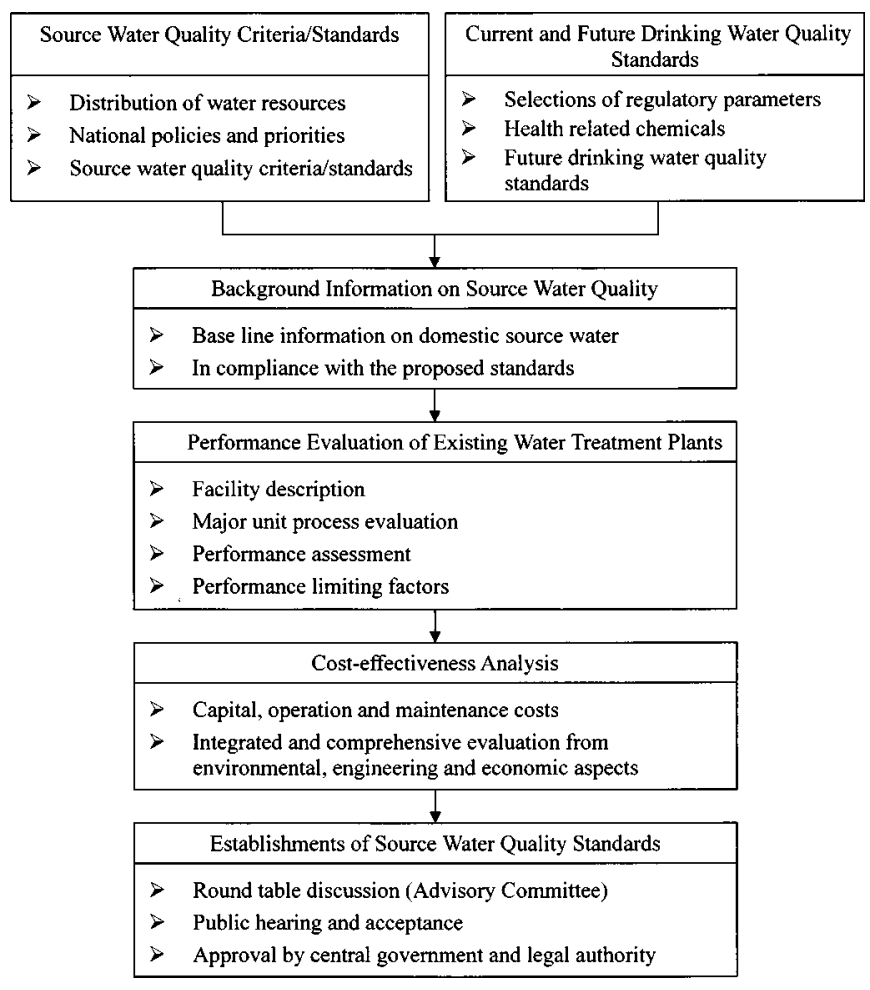

Fig. 1. Procedures to develop the source water quality standards in Taiwan

The objective of this research work is intended to review the current status of source water as compared with the source water quality promulgated in 1997. Total coliforms, total organic carbon (TOC) and chemical oxygen demand (COD) were selected as the major parameters because of their specific characteristic associated with the disinfection efficiency and disinfection by-products (DBPs) formation potentials. The average values of total coliforms, TOC, and COD are below 10,000 CFU/100 mL, $2 \mathrm{mg} / \mathrm{L}$, and $15 \mathrm{mg} / \mathrm{L}$ in uncontaminated source water in Taiwan, respectively (Chiang et al. 2001). These parameters are routinely measured and cannot comply with the source water quality standards all the time. Besides, these parameters have the characteristics of availability, representative, precision, and accuracy for review to determine if any further revision should be made. The future source water quality standards have been proposed as a result of the present study.

\section{Rationale for Determination of Source Water Quality Standards}

In selecting water quality parameters for source water quality standards, each enforceable parameter should be a representative indicator for water pollution including toxic and hazardous substances. In determining the regulatory limits of each parameter, the following factors should be considered: (1) source water quality criteria and standards from nations around the world; (2) current and future drinking water standards; (3) background information on source water quality; (4) performance evaluation of existing water treatment plants; and (5) cost-effectiveness analysis. Fig. 1 presents the procedures to develop the existing source water quality standards in Taiwan (Chang et al. 1998, 1999).
The general principles regarding the above evaluation factors are stated as follows.

1. Source water quality criteria/standards from nations around the world. Since there are differences in the distribution of water resources, policies, and national priorities, the source water quality standards of various nations were adopted to suit the needs of each country in achieving predetermined goals.

The major sustainable indicators for water quality assessment would depend on the designated use of a water body. The United States Water Pollution Act (Public Law 92-500, commonly known as the Clean Water Act) requires each State to conduct water quality surveys to determine the overall health of all water bodies. Under this survey, each State is responsible for designating its rivers and streams for State-specific use. For example, Maryland classified streams within its State boundary into 7 categories in order to comply with the requirements stipulated in the Clean Water Act. The major sustainable indicators for water quality assessment of a stream designated for public water supply purpose in Maryland are fecal coliform, dissolved oxygen (DO), temperature, $\mathrm{pH}$, turbidity, and toxic substances (Code of Maryland Regulation). In the meanwhile, California takes BOD, coliform, DO, pH, chlorides, iron and manganese together with fluorides, phenolic compounds, color and turbidity as the source water indicators (Van der Leeden et al. 1990).

The Japanese Government classifies rivers and lakes into A, B, $\mathrm{C}$ categories according to the level of water quality for water purification treatment methods in waterworks. Indicators of $\mathrm{pH}$, BOD, suspended solids, DO, and coliform groups are chosen to classify the source water quality. Besides these water quality parameters listed in the environmental quality standards, THM formation potential, and $\mathrm{NH}_{3}-\mathrm{N}$ are of special concern regarding source water protection (Sato 2002).

In addition to the above-noted information, the promulgated criteria/standards for different countries were summarized in Table 1 as baseline information for determining standards in Taiwan.

2. Current and future drinking water quality standards. The concept of human health risk assessment should be introduced to amend drinking water quality standards in Taiwan, especially for the DBPs and heavy metals. The purpose of regulating source water quality is to produce finished water from traditional coagulation-precipitation water treatment processes to meet existing drinking water standards. Future drinking water standards must also be considered while setting source water quality standards.

3. Background information on source water quality. Every country establishes its own water quality standards based on special domestic needs and characteristics. Recently, the Taiwan EPA has conducted a long-term, integrated and comprehensive project to establish the national drinking water quality standards. A full analysis of relevant background information on water sources and treated water is the key factor leading to a better understanding of how well actual water quality has lived up to the established standards.

It is noted that excessively stringent source water quality standards may not be practical and will certainly increase water treatment costs. Thus, less stringent source water quality standards comparable to the existing water quality may be adopted initially and tightened gradually in phases to avoid sudden impacts to the water supply industry as well as consumers. Mechanisms for this should be established, such as specific statutory deadlines, water rate design, and cost allocation to upgrade the performance and capacity for water treatment plant. 
Table 1. Comparison of Source Water Quality Criteria/Standards in Various Nations

\begin{tabular}{|c|c|c|c|c|c|c|c|c|}
\hline \multirow[b]{2}{*}{ Parameter units } & \multirow[b]{2}{*}{ USEPA $^{\mathrm{a}}$} & \multirow[b]{2}{*}{$\begin{array}{l}\text { Alberta } \\
\text { Canada }\end{array}$} & \multirow[b]{2}{*}{$\begin{array}{l}\mathrm{EC} \\
\text { (A1) }\end{array}$} & \multirow[b]{2}{*}{ Japan } & \multirow[b]{2}{*}{ Australia } & \multirow[b]{2}{*}{$\begin{array}{c}\text { Germany } \\
\text { (Rhine River) }\end{array}$} & \multicolumn{2}{|c|}{ Taiwan } \\
\hline & & & & & & & Current & Future \\
\hline \multicolumn{9}{|l|}{ I. Microorganisms } \\
\hline $\begin{array}{l}\text { Total coliforms } \\
\text { (CFU/100 mL) }\end{array}$ & 20,000 & 5,000 & - & 5,000 & $<10$ & - & 20,000 & 10,000 \\
\hline $\begin{array}{l}\text { Fecal coliforms } \\
\text { (CFU/100 mL) }\end{array}$ & 2,000 & 1,000 & - & - & ND & - & - & - \\
\hline \multicolumn{9}{|l|}{ II. Physical parameters } \\
\hline Color $(\mathrm{CU})$ & - & $\leqslant 30$ & 20 & 10 & 15 & 0.5 & - & - \\
\hline $\mathrm{pH}$ & $5.0-9.0$ & $6.5-8.5$ & - & $6.5-8.5$ & $6.5-8.5$ & $6.5-8.5$ & - & - \\
\hline \multicolumn{9}{|l|}{ III. Inorganics } \\
\hline As $(\mu g / L)$ & 10 & 10 & 50 & 10 & 1 & 5 & 50 & 50 \\
\hline $\mathrm{Ba}(\mu \mathrm{g} / \mathrm{L})$ & 1,000 & 1,000 & 50 & - & 1 & 700 & - & - \\
\hline $\mathrm{Cr}(\mu \mathrm{g} / \mathrm{L})$ & - & 20 & 50 & 50 & 0.01 & 25 & 50 & 50 \\
\hline $\mathrm{Cd}(\mu \mathrm{g} / \mathrm{L})$ & - & 10 & 5 & 10 & 0.06 & 3 & 10 & 5 \\
\hline $\mathrm{Hg}(\mu \mathrm{g} / \mathrm{L})$ & - & 0.1 & 1 & 0.5 & 0.06 & 0.5 & 2 & 1 \\
\hline $\mathrm{Pb}(\mu \mathrm{g} / \mathrm{L})$ & - & 50 & 50 & 10 & 1.0 & 5 & 50 & 50 \\
\hline $\operatorname{Se}(\mu g / L)$ & 170 & 10 & 10 & 10 & 5 & 5 & 50 & 10 \\
\hline $\mathrm{Ag}(\mu \mathrm{g} / \mathrm{L})$ & - & 50 & - & - & 0.02 & - & - & - \\
\hline $\mathrm{Cu}(\mu \mathrm{g} / \mathrm{L})$ & 1,300 & 20 & 50 & 1,000 & 1.0 & - & - & - \\
\hline $\mathrm{Fe}(\mu \mathrm{g} / \mathrm{L})$ & 300 & 300 & 300 & 300 & - & - & - & - \\
\hline $\operatorname{Mn}(\mu \mathrm{g} / \mathrm{L})$ & 50 & 50 & - & 20 & 1,200 & - & - & - \\
\hline $\mathrm{Zn}(\mu \mathrm{g} / \mathrm{L})$ & 7,400 & 50 & 3,000 & 1,000 & 2.4 & - & - & - \\
\hline $\mathrm{NH}_{3}-\mathrm{N}(\mathrm{mg} / \mathrm{L})$ & - & 1 (TKN) & - & 0.5 & 0.32 & 0.3 & 1 & - \\
\hline $\mathrm{Cl}^{-}(\mathrm{mg} / \mathrm{L})$ & - & 1.5 & - & 200 & 0.0004 & 100 & - & - \\
\hline $\mathrm{CN}^{-}(\mu \mathrm{g} / \mathrm{L})$ & 700 & 15 & 50 & 10 & 0.004 & 25 & - & - \\
\hline $\mathrm{NO}_{3}^{-}(\mathrm{mg} / \mathrm{L})$ & 10 & - & 50 & 9 & 0.00017 & - & - & - \\
\hline $\mathrm{SO}_{4}^{2-}(\mathrm{mg} / \mathrm{L})$ & - & $0.05\left(\mathrm{~S}^{2-}\right)$ & 250 & - & 0.0005 & 100 & - & - \\
\hline \multicolumn{9}{|l|}{ IV. Organics } \\
\hline $\begin{array}{l}\text { Surfactants (MBAS) } \\
(\mu \mathrm{g} / \mathrm{L})\end{array}$ & - & - & - & 500 & - & - & - & - \\
\hline Phenol $(\mu \mathrm{g} / \mathrm{L})$ & 21,000 & 5 & 1 & 5 & 85 & - & - & - \\
\hline $\begin{array}{l}\text { Total pesticides } \\
(\mu \mathrm{g} / \mathrm{L})\end{array}$ & - & - & 0.2 & - & - & 50 & - & - \\
\hline COD (mg/L) & - & - & - & $\begin{array}{c}3 \\
\left(\mathrm{KMnO}_{4}\right)\end{array}$ & - & - & $\begin{array}{c}25 \\
\left(\mathrm{~K}_{2} \mathrm{Cr}_{2} \mathrm{O}_{7}\right)\end{array}$ & 20 \\
\hline $\operatorname{PCB}^{c}(\mu \mathrm{g} / \mathrm{L})$ & 0.00064 & - & - & $\mathrm{ND}^{\mathrm{b}}$ & - & - & - & - \\
\hline $\mathrm{PAHs}^{\mathrm{d}}(\mu \mathrm{g} / \mathrm{L})$ & - & - & 0.2 & - & - & 0.1 & - & - \\
\hline TOC (mg/L) & - & - & - & - & - & 3 (DOC) & 4 & 2 \\
\hline
\end{tabular}

Note: $\mathrm{TOC}=$ total organic carbon.

${ }^{a}$ U.S. Environmental Protection Agency (USEPA) national recommended water quality criteria: 2002, for consumption of "water+organism."

${ }^{\mathrm{b}}$ Not detectable.

${ }^{\mathrm{c}}$ Polychlorinated biphenyls.

${ }^{\mathrm{d}}$ Polycyclic aromatic hydrocarbon.

4. Performance evaluation of existing water treatment plants. Prior to determining source water quality standards, it is necessary to evaluate the treatment capacity of existing water plants in treating raw water at predetermined water quality standards and in meeting drinking water quality standards. An unreasonable standard may result in excessive treatment costs for water treatment plants. Most water purification facilities in Taiwan still rely on traditional methods, i.e., coagulation, sedimentation, filtration, and chlorination. The efficiency of these methods for achieving the target water quality parameters should be taken into consideration when establishing interim standards.

5. Cost-effectiveness analysis. Chemical and microbial water quality criteria, supplemented with a limited number of biological water quality criteria, are the principal indicators of water quality used in the developed nations at this time. However, the implementation of more integrated and comprehensive indicators of environmental health and biological diversity need great efforts to be developed.

Before adopting standards, it is recommended that the costeffectiveness analysis be conducted to evaluate if the new standards or criteria will cause compliance difficulties. If poor source water quality affects the operating performance of water treatment processes, the water supply company should define performance goals for each water treatment process.

In summary, to protect public health, pathogens and toxic substances including arsenic, lead, chromium, mercury, cadmium, 
Table 2. Evaluation of Microbial Indicators in Water Quality Criteria/Guidelines for the Developed Nations

\begin{tabular}{|c|c|c|c|c|c|}
\hline $\begin{array}{l}\text { Micro-biological } \\
\text { contaminants }\end{array}$ & $\begin{array}{c}\text { Drinking water } \\
\text { management regulation }\end{array}$ & $\begin{array}{c}\text { Source water } \\
\text { management regulation }\end{array}$ & $\begin{array}{l}\text { Occurrence in } \\
\text { source water }\end{array}$ & $\begin{array}{l}\text { Health } \\
\text { effect }\end{array}$ & $\begin{array}{l}\text { Disinfection } \\
\text { efficiency }\end{array}$ \\
\hline Total coliforms & $\begin{array}{l}\text { United States, Japan, England, } \\
\text { Canada (Alberta), Germany }\end{array}$ & $\begin{array}{l}\text { United States, United States } \\
\text { (California), Canada } \\
\text { (Alberta), Japan, Australia }\end{array}$ & High & Low & High \\
\hline Fecal coliforms & Unites States, EC, Australia & $\begin{array}{c}\text { United States, Canada (Alberta), } \\
\text { Australia }\end{array}$ & Medium & Medium & High \\
\hline E Coli & $\begin{array}{c}\text { Unites States, WHO, Germany, EC, } \\
\text { Australia, } \\
\text { England, Canada (Alberta), } \\
\text { New Zealand,Holland }\end{array}$ & Canada (Alberta), France & Low & High & High \\
\hline $\begin{array}{l}\text { Fecal } \\
\text { streptococci }\end{array}$ & Germany, EC & France & Medium & Medium & High \\
\hline Enteroccoci & EC, England, Holland & Canada (Alberta) & Low & Medium & Medium \\
\hline $\begin{array}{l}\text { Pseudomonas } \\
\text { aeruginosa }\end{array}$ & - & Canada (Alberta) & Low & Low & Low \\
\hline Cryptosporidium & United States, Holland & - & Low & High & High \\
\hline Giardia lambia & United States, Holland & - & Low & High & High \\
\hline Cyanobacteria & New Zealand & - & Low & High & High \\
\hline Pathogenic bacteria & New Zealand & - & Low & High & Medium \\
\hline Protozoa (pathogenic) & New Zealand & - & Low & High & Medium \\
\hline Helminths (pathogenic) & New Zealand & - & Low & High & Medium \\
\hline Algae & New Zealand & - & High & Medium & Low \\
\hline Virus & $\begin{array}{l}\text { New Zealand, United States } \\
\text { (enteric virus), Holland }\end{array}$ & - & Low & High & Low \\
\hline Thermotolerant & Australia, WHO & - & Low & Medium & Low \\
\hline
\end{tabular}

and selenium should be regulated. In setting source water quality standards for these toxic substances, it must be noted that conventional water treatment plants may not effectively remove these substances. Therefore, the source water quality standards for these substances should be set as equal to the drinking water standards. However, it is recommended that the source water standards be compared with those from other countries to reduce the health risk in existing source water quality in Taiwan before being finalized. Other regulatory parameters including coliform bacteria, ammonia, COD, and TOC should be based mainly on existing source water quality.

\section{Development of Microbial Indicators in Source Water Quality Standards}

In general, low counts of fecal coliforms and E. Coli are indicative of safe waters but not always. Table 2 evaluates the microbial indicators in source water criteria/guidelines for the developed nations from the aspects of regulation, occurrence, and health effect. It is suggested in this paper that total coliforms, despite its low correlation with health effect should be a representative parameter due to its unique characteristics in conjunction with the source water management regulations, and effective assessment in disinfection efficiency.

The Taiwanese source water standards require that total coliforms cannot exceed 20,000 CFU/100 mL for plants with traditional facilities and $50 \mathrm{CFU} / 100 \mathrm{~mL}$ for plants with only disinfection treatment. The total coliform standards adopted by California (United States), Canada, and Japan are divided into several categories according to the selected treatment processes (Table 3). They regulate that high total coliform levels require more ad- vanced treatment processes to meet the drinking water standards at the point of service.

The concentration profiles of total coliform in source water published by the Taiwan Water Company for the periods of 19951996 and 1997-1998 are shown in Fig. 2. Total coliform concentrations in source water greater than 20,000 CFU/100 mL were 9 and $8 \%$ of the total samples in 1995-1996 and 1997-1998, respectively. Total coliform concentrations in source water greater than $10,000 \mathrm{CFU} / 100 \mathrm{~mL}$ were about $15 \%$ of the total samples for both periods. There was a slightly decreasing trend of the average concentration of total coliforms which suggests that there is an improvement in the source water quality.

Acceptable disinfection efficiency was set at $99.99 \%$ inactivation of the total coliform count (the average level of total coliforms measured in source water is about 30,000 CFU/100 mL), which would also meet the Taiwan EPA drinking water standard $(6 \mathrm{CFU} / 100 \mathrm{~mL})$. All water treatment plants with total coliform violations in source water standards are equipped with pre-chlorination facilities. Since excessive chlorine residual and disinfection by-products have not been found in the finished water, most of the plants can meet the current drinking water standards. However, the slow improvement in source water protection makes it unlikely that source water standards will be met by some of the water treatment plants in the near future. As a result, it suggests that a source water total coliform standard of $10,000 \mathrm{CFU} / 100 \mathrm{~mL}$ be adopted in 2006 and be enforced to $5,000 \mathrm{CFU} / 100 \mathrm{~mL}$ in 2007. The following items should also be addressed in the source water quality regulations: the growing concern of the presence of DBPs in the finished water, as well as disinfection efficiency measured by $C \times T$ (chlorine dose-contact time) values.

It is noted that on the aspect of pathogen, there is a current 
Table 3. Source Water Quality Standards for Total Coliforms in Various Nations

\begin{tabular}{|c|c|c|c|}
\hline Nations & Standard & Unit & Remarks \\
\hline Taiwan (ROC) (1997) & $\begin{array}{l}\text { I. } 20,000 \\
\text { II. } 50\end{array}$ & $\begin{array}{l}\mathrm{MPN} / 100 \mathrm{~mL} \\
\quad \text { or } \\
\mathrm{CFU} / 100 \mathrm{~mL}\end{array}$ & \\
\hline USEPA (1972) & $<20,000$ & $\mathrm{CFU} / 100 \mathrm{~mL}$ & Used for public water supplies \\
\hline \multirow[t]{3}{*}{ California, United States } & I. $50-100$ & MPN/100 mL & $\begin{array}{l}\text { I. Excellent grade; safe drinking water } \\
\text { treated by disinfection }\end{array}$ \\
\hline & II. $240-5,000$ & & $\begin{array}{l}\text { II. Good grade, water treated by } \\
\text { conventional water treatment plant }\end{array}$ \\
\hline & III. $10,000-20,000$ & & $\begin{array}{l}\text { III. Poor grade, water treated by advanced } \\
\text { or specialized treatment processes }\end{array}$ \\
\hline \multirow[t]{4}{*}{ Canada (1995) } & I. 0 & $\mathrm{CFU} / 100 \mathrm{~mL}$ & I. Without treatment \\
\hline & II. 10 & & $\begin{array}{l}\text { II. Only treated by disinfection (allowed }<20 \% \\
\text { samples exceeding } 5000 \\
\text { MPN/100 mL) }\end{array}$ \\
\hline & III. 100 & & $\begin{array}{l}\text { III. Partialy treated by conventional } \\
\text { treatment processes (allowed }<5 \% \\
\text { samples exceeding } 20,000 \mathrm{MPN} / 100 \mathrm{~mL} \text { ) }\end{array}$ \\
\hline & IV. N/A & & $\begin{array}{l}\text { IV. Completely treated by conventional } \\
\text { treatment processes (allowed }<10 \% \\
\text { samples exceeding } 10 / 100 \mathrm{MPN} / 100 \mathrm{~mL} \text { ) }\end{array}$ \\
\hline Alberta, Canada (1993) & 5,000 & $\mathrm{CFU} / 100 \mathrm{~mL}$ & Based on surface water quality criteria \\
\hline \multirow[t]{3}{*}{ Japan (1975) } & I. 50 & $\mathrm{MPN} / 100 \mathrm{~mL}$ & I. Without treatment \\
\hline & II. 1,000 & & II. Only treated by disinfection \\
\hline & III. 5,000 & & $\begin{array}{l}\text { III. Partialy treated by conventional } \\
\text { treatment processes }\end{array}$ \\
\hline \multirow[t]{3}{*}{ Australia (1992) } & I. & $\mathrm{CFU} / 100 \mathrm{~mL}$ & $\begin{array}{l}\text { I. Up to ten coliform organisms may be } \\
\text { occasionally accepted in } 100 \mathrm{~mL}\end{array}$ \\
\hline & II. & & $\begin{array}{l}\text { II. Coliform organisms should not be } \\
\text { detactable in } 100 \mathrm{~mL} \text { of any two } \\
\text { consecutive samples }\end{array}$ \\
\hline & III. & & $\begin{array}{l}\text { III. Throughout any year, } 95 \% \text { of samples } \\
\text { should not contain any coliform } \\
\text { organisms in } 100 \mathrm{~mL}\end{array}$ \\
\hline
\end{tabular}

search for a good measure or indicator for Giardia and Cryptosporidium. There is also a desire to find better indicators of human wastewater influence, such as caffeine and coprostanol (Tien 2002). There are developing tools in the field of genetics, for instance, DNA tracking is allowing us to identify the actual source of fecal contamination (e.g., humans, birds, dogs) How-

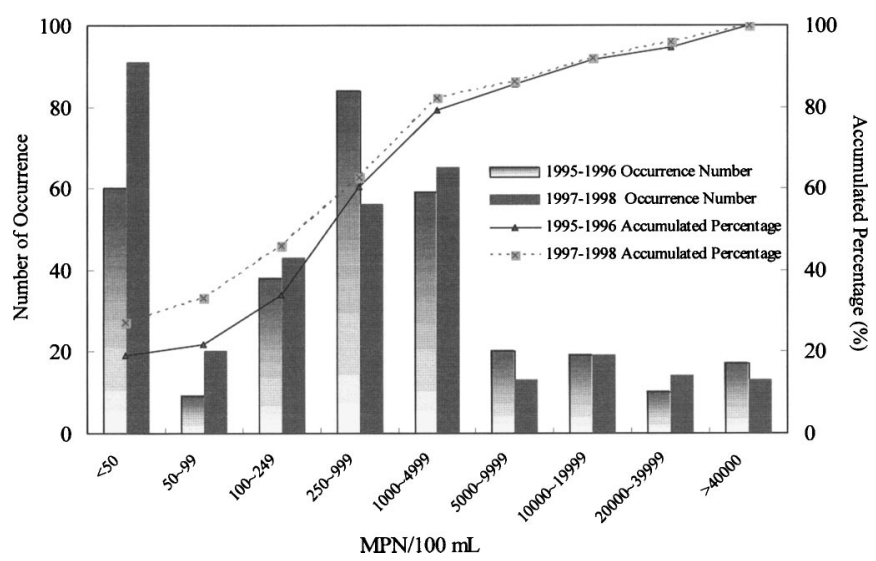

Fig. 2. The concentration profiles of total coliforms in source water utilized by the Taiwan Water Company during 1995-1996 and 19971998. ever, these newly developing microbial indicators need more data base to assess its potency for drinking water supplies (Tien 2002).

\section{Development of Organic Indicators in Source Water Quality Standards}

UV absorption, a useful surrogate measurement of selected organic constituents in fresh water (Wilson 1959; Dobbs et al. 1972; Copper and Young 1984), may exhibit strong correlation with organic carbon content, color, and precursors of DBPs (Edzwald et al. 1985). The COD is used as a measurement of the oxygen equivalent of the organic matter content in water that is susceptible to oxidation by a strong chemical oxidant. TOC is a more convenient and direct expression of total organic content and can be used to evaluate the effects of DBP control strategies. Singer et al. (1995) suggested that chlorine consumption was a reasonably good indicator of DBP formation.

In a previous study, Chang et al. (1998) found that COD had strong correlation with $\mathrm{UV}_{254}$ (or humid substance) and chlorine demand in different source water samples with different characteristics. Table 4 evaluates the organic indicators utilized in the source water which suggests that COD and TOC should be regarded as surrogate parameters for source water quality analyses and precursors of DBP concerns. 
Table 4. Evaluation of Organic Indicators in Source Water Quality Analyses

\begin{tabular}{|c|c|c|c|c|c|}
\hline Factors to be considered & $\begin{array}{c}\text { COD } \\
(\mathrm{mg} / \mathrm{L})\end{array}$ & $\begin{array}{c}\text { TOC } \\
(\mathrm{mg} / \mathrm{L})\end{array}$ & $\begin{array}{c}\mathrm{Cl}_{2} \text { demand } \\
(\mathrm{mg} / \mathrm{L})\end{array}$ & $\mathrm{UV}_{254}$ & $\begin{array}{c}\text { Humic } \\
\text { substances }\end{array}$ \\
\hline \multicolumn{6}{|l|}{ Background information } \\
\hline International availability & +++ & ++++ & + & +++ & ++ \\
\hline National availability & +++ & +++ & + & ++ & + \\
\hline Representative & +++ & +++ & ++ & ++ & +++ \\
\hline \multicolumn{6}{|l|}{ Water treatment technology } \\
\hline Monitoring parameters & + & ++++ & ++ & ++ & + \\
\hline \multicolumn{6}{|l|}{ Analytical technique } \\
\hline Precision/Accuracy & +++ & +++ & + & ++++ & ++ \\
\hline Time consumption & ++ & +++ & ++ & ++++ & + \\
\hline Equipment/Apparatus cost & +++ & + & ++++ & ++ & + \\
\hline Ease of operation & ++ & +++ & + & ++++ & + \\
\hline Related to DBPs formation & + & +++ & + & +++ & ++++ \\
\hline
\end{tabular}

Note: $\mathrm{COD}=$ chemical oxygen demand; and $\mathrm{TOC}=$ total organic carbon. The "+" symbol denotes the advantages of the parameter with the corresponding event. The potency of the advantage increases as the number of "+" increases.

\section{Total Organic Carbon}

Around the world, Germany is the only country that regulates dissolved organic carbon (DOC) in the source water. Germany set a limit of $3 \mathrm{mg} / \mathrm{L}$ DOC for the Rhine River cleanup project. To protect the public health, the Information Collection Rules (ICR) of the USEPA suggests that a public water system serving more than 100,000 persons must monitor DBPs in the finished water and TOC in the source water. The ICR also requires batch tests for DBP precursors as well as pilot plant tests. However, water suppliers can be exempted from this requirement if the quarterly average of THMs is less than $40 \mu \mathrm{g} / \mathrm{L}$ and HAAs is less than $30 \mu \mathrm{g} / \mathrm{L}$ or the yearly average of TOC is less than $4 \mathrm{mg} / \mathrm{L}$ in the influent. Besides, THM/HAA must be no greater than $40 / 30 \mu \mathrm{g} / \mathrm{L}$ under Stage 2 of the USEPA D/DBP Rule (to be enforced after 2004).

From 1994-2000, the Taiwan EPA supported a research project which involved evaluation of the source water quality in Taiwanese water treatment plants (Table 5). The results of this investigation indicated that $25 \%$ of the samples had a TOC greater than $2 \mathrm{mg} / \mathrm{L}(n=46)$. Also, $13 \%$ of the samples had a

Table 5. Analyses of Total Organic Carbon in Source Water at Various Water Treatment Plants

\begin{tabular}{lccc}
\hline $\begin{array}{l}\text { Water treatment } \\
\text { plant code }\end{array}$ & $\begin{array}{c}\text { Average } \\
(\mathrm{mg} / \mathrm{L})\end{array}$ & $\begin{array}{c}\text { Range } \\
(\mathrm{mg} / \mathrm{L})\end{array}$ & Sample size \\
\hline $\mathrm{A}$ & 1.4 & $0.59-2.73$ & 45 \\
$\mathrm{~B}$ & 0.8 & $1.47-1.35$ & 25 \\
$\mathrm{C}$ & 2.6 & $1.42-7.20$ & 23 \\
$\mathrm{D}$ & 1.1 & $0.63-3.16$ & 9 \\
$\mathrm{E}$ & 0.3 & $0.24-0.32$ & 4 \\
$\mathrm{~F}$ & 1.0 & $0.44-1.90$ & 19 \\
$\mathrm{G}$ & 2.2 & $0.95-8.03$ & 13 \\
$\mathrm{H}$ & 1.6 & $0.81-3.41$ & 10 \\
$\mathrm{I}$ & 0.6 & $0.29-1.15$ & 7 \\
$\mathrm{~J}$ & 1.5 & $0.68-3.40$ & 5 \\
$\mathrm{~K}$ & 2.3 & $1.16-5.04$ & 6 \\
$\mathrm{~L}$ & 1.8 & $1.50-2.20$ & 5 \\
$\mathrm{M}$ & 4.9 & $3.82-6.57$ & 5 \\
$\mathrm{~N}$ & 10.2 & $7.03-14.41$ & 5 \\
$\mathrm{O}$ & 9.9 & $8.99-11.54$ & 4 \\
\hline
\end{tabular}

TOC greater than $3 \mathrm{mg} / \mathrm{L}$. Based on the average TOC value of each water plant, there were 6 water plants with an average TOC greater than $2 \mathrm{mg} / \mathrm{L}$ and 3 plants with TOC greater than $3 \mathrm{mg} / \mathrm{L}$. It is also noted that of the 12 samples with a TOC concentration in source water less than $2 \mathrm{mg} / \mathrm{L}$, only 1 had a total THM concentration greater than $40 \mu \mathrm{g} / \mathrm{L}$. This implies that if the TOC standard is set at $2 \mathrm{mg} / \mathrm{L}$, it will significantly decrease the DBP concentrations in the finished water. The water authority is urged to adopt this TOC standard to achieve the goal of minimizing the formation of DBPs in the finished water. This proposal is very consistent with previous research findings (Chiang et al. 1997) presented in Fig. 3, which indicates that the formation of THMs increases with TOC. For instance, at a contact time of $40 \mathrm{~min}$, and $\mathrm{TOC}=4 \mathrm{mg} / \mathrm{L}$, the concentration of THMs is approximately double that formed when $\mathrm{TOC}=3 \mathrm{mg} / \mathrm{L}$ at the same contact time. Therefore, the TOC concentration prior to the application of disinfectant should be kept under $3 \mathrm{mg} / \mathrm{L}$ to meet the more stringent THM standard of $60 \mu \mathrm{g} / \mathrm{L}$.

According to the above-mentioned data, TOC in some Taiwanese source water is low. A standard of $3 \mathrm{mg} / \mathrm{L}$ TOC should not greatly affect compliance and we therefore recommend that this be enforced in 2005. In 2007, the standard should be reduced to $2 \mathrm{mg} / \mathrm{L}$. To enforce the source water TOC standard, the regula-

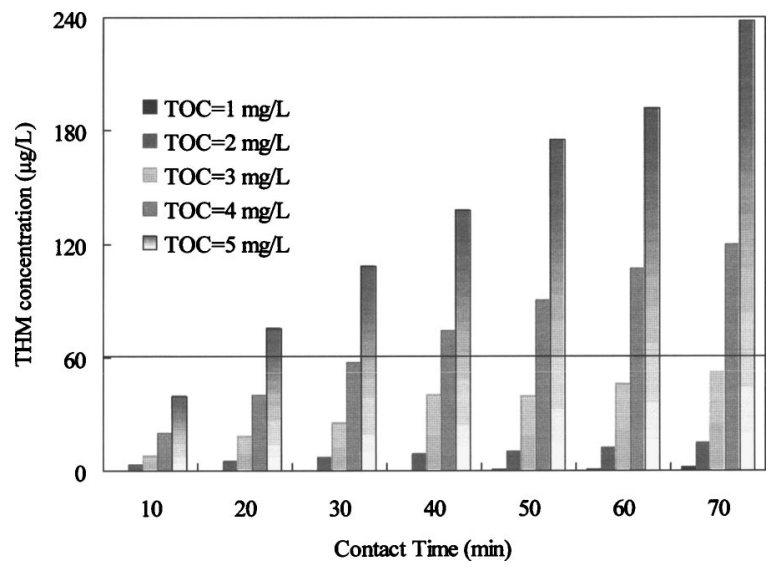

Fig. 3. Effects of total organic carbon ) concentration on THM formation at applied chlorine dose $=2.0 \mathrm{mg} / \mathrm{L}$ for various levels of contact time 
Table 6. Source Water Quality Standards for Chemical Oxygen Demand $(\mathrm{mg} / \mathrm{L})$ in Various Nations

\begin{tabular}{|c|c|c|}
\hline Nations & $\begin{array}{l}\text { Standard } \\
(\mathrm{mg} / \mathrm{L})\end{array}$ & Remarks \\
\hline \multirow{2}{*}{$\begin{array}{l}\text { Taiwan } \\
\text { (ROC) } \\
(1997)\end{array}$} & I. 25 & $\begin{array}{l}\text { I: Surface water or ground water used for water } \\
\text { supplies and small systems }\end{array}$ \\
\hline & II. - & $\begin{array}{l}\text { II: Surface water or ground water used for small } \\
\text { community, bottled or packaged water }\end{array}$ \\
\hline \multirow[t]{3}{*}{$\begin{array}{l}\mathrm{Japan}^{\mathrm{a}} \\
(1975)\end{array}$} & $\begin{array}{l}\text { I. } 1 \\
\text { II. } 2\end{array}$ & $\begin{array}{l}\text { I: Simple purification, i.e., filtration and } \\
\text { disinfection }\end{array}$ \\
\hline & III.3 & $\begin{array}{l}\text { II: Conventional treatment process, i.e., } \\
\text { coagulation, filtration, and disinfection }\end{array}$ \\
\hline & & $\begin{array}{l}\text { III: Advanced treatment processes, i.e., activated } \\
\text { carbon, and ozonation }\end{array}$ \\
\hline \multirow[t]{2}{*}{ France } & 1A. 20 & 1A: Ideal value \\
\hline & 2A. $20-25$ & 2A: Allowable value \\
\hline \multirow[t]{3}{*}{$\begin{array}{l}\text { EC } \\
(1975)\end{array}$} & $\begin{array}{l}\text { A1. - } \\
\text { A2. - }\end{array}$ & $\begin{array}{l}\text { A1: Simple purification, i.e., filtration and } \\
\text { disinfection }\end{array}$ \\
\hline & & $\begin{array}{l}\text { A2: Conventional treatment process, i.e., } \\
\text { coagulation, filtration, and disinfection }\end{array}$ \\
\hline & A3. 30 & $\begin{array}{l}\text { A3: Enhanced treatment processes, i.e., activated } \\
\text { carbon, and ozonation }\end{array}$ \\
\hline
\end{tabular}

${ }^{a}$ Determined by using $\mathrm{KMnO}_{4}$ as an oxidized agent.

tory agency can follow the requirements stipulated by the USEPA ICR, i.e., THM/HAA must meet $40 / 30 \mu \mathrm{g} / \mathrm{L}$ when TOC exceeds the standard. Otherwise, a source water improvement plan of quality must be implemented.

\section{Chemical Oxygen Demand}

In reviewing the source water COD standard adopted by various countries, it was found that France adopted an ideal standard of $20 \mathrm{mg} / \mathrm{L}$ and allowable value of $20-25 \mathrm{mg} / \mathrm{L}$ (Table 6). EC assigned a COD guideline value of $30 \mathrm{mg} / \mathrm{L}$ for enhanced treatment process (EC 1975). Japanese COD standards range from 1 to $3 \mathrm{mg} / \mathrm{L}$, using $\mathrm{KMnO}_{4}$ as an oxidation agent (Kikuchi 1975). In 1998, the Taiwanese Water Company reported that six water treatment plants violated the source water COD standard.

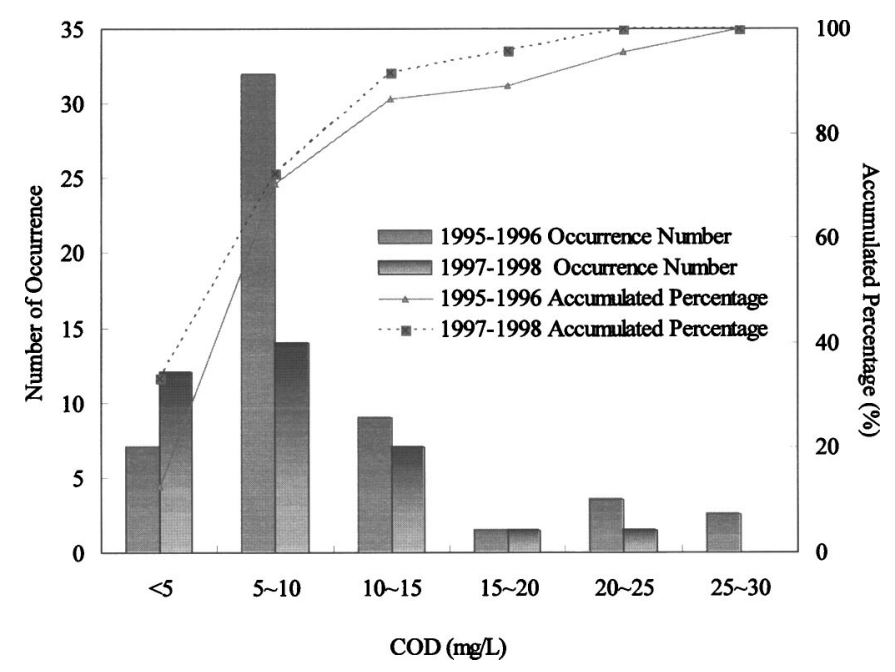

Fig. 4. The concentration profiles of chemical oxygen demand in source water utilized by the Taiwan Water Company during 19951996 and 1997-1998
Table 7. Revised Source Water Quality Standards for Total Coliforms, total organic carbon (TOC), chemical oxygen demand (COD) in Taiwan (ROC)

\begin{tabular}{|c|c|c|c|c|c|c|}
\hline $\begin{array}{l}\text { Parameters } \\
\text { (Units) }\end{array}$ & Standard & 2003 & 2004 & 2005 & 2006 & 2007 \\
\hline $\begin{array}{l}\text { Total } \\
\text { coliforms }\end{array}$ & 20000 & 0 & & & & \\
\hline $\begin{array}{l}\text { (CFU/100 mL } \\
\text { or }\end{array}$ & 10000 & O... &.- & $(9)$ & 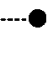 & \\
\hline $\mathrm{MPN} / 100 \mathrm{~mL}$ ) & 5000 & 0 & 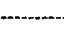 & 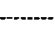 & $-\cdots$ & -.---o \\
\hline \multirow{3}{*}{$\begin{array}{l}\text { TOC } \\
(\mathrm{mg} / \mathrm{L})\end{array}$} & 4 & - & & & & \\
\hline & $3^{*}$ & $0 \cdots$ & -..-(0)- & $\cdots$ & & \\
\hline & $2^{*}$ & O- & ........ & .......... & (0) & ....... \\
\hline \multirow{3}{*}{$\begin{array}{l}\mathrm{COD} \\
(\mathrm{mg} / \mathrm{L})\end{array}$} & 25 & - & & & & \\
\hline & 20 & 0 & .......... & c & -1.. & \\
\hline & 15 & O-.. & & & $\cdots$ & $\cdots$ \\
\hline \multicolumn{7}{|c|}{$\bar{O}$ : Proposed Regulations } \\
\hline \multicolumn{7}{|c|}{ (9) : Final Regulations } \\
\hline \multicolumn{7}{|c|}{$\begin{array}{l}\text { : Regulations Effective } \\
\text { *: TTHM/THAA must mee }\end{array}$} \\
\hline
\end{tabular}

According to the 1997-1998 Background Surface Source Water Quality Report submitted by the Taiwan Water Company for 40 water treatment plants, there was a $5 \%$ chance ( 2 out of 40 plants) that the average COD in source water exceeded $15 \mathrm{mg} / \mathrm{L}$ (Fig. 4). By reviewing the maximum COD values submitted, there was a $27 \%$ chance (11 out of 40 plants) that COD was greater than $15 \mathrm{mg} / \mathrm{L}$ and a $7 \%$ chance (3 out of 40 plants) that COD was greater than $20 \mathrm{mg} / \mathrm{L}$. Compared with the existing COD standard $(25 \mathrm{mg} / \mathrm{L})$ for source water, the background COD concentration in source water was relatively low. It implies that the existing $(25 \mathrm{mg} / \mathrm{L}) \mathrm{COD}$ standard is too lenient to protect source water quality. After reviewing source water samples $(n=32)$ taken from seven water treatment plants for this investigation, it was found that 8 samples had COD between 15 and $25 \mathrm{mg} / \mathrm{L}$, and $63 \%$ of these 8 samples had total THM greater than $40 \mu \mathrm{g} / \mathrm{L}$. Among the 19 samples with COD less than $15 \mathrm{mg} / \mathrm{L}$, there is a $32 \%$ chance that THM is greater than $40 \mu \mathrm{g} / \mathrm{L}$. These statistical data suggest that a source water COD standard of $15 \mathrm{mg} / \mathrm{L}$ would minimize the risk of producing DBPs. The existing source water quality should not have much difficulty in meeting the COD standard of $15 \mathrm{mg} / \mathrm{L}$. Consequently, it is recommended that a COD standard of $20 \mathrm{mg} / \mathrm{L}$ be adopted in 2006 (similar to France 1A COD standard) and reduced to $15 \mathrm{mg} / \mathrm{L}$ in 2007.

On the other hand, several technical advisory meetings were conducted to solicit input from experts regarding source water standards in Taiwan. It also suggests that Taiwan source water quality should be revised in phases according to the proposed total coliforms, TOC, and COD standards because there are technical problems associated with the enforcement of these standards at the present time. That is, a uniform single standard should be adopted in Phase I which can be divided into two stages as shown in Table 7 and additional regulated parameters will be amended in Phase II after objectives of source water protection in Phase I are accomplished.

\section{Implementation Plans}

The water treatment plant with unacceptable source water quality needs to improve its source water quality and establish the imple- 
mentation plan based on the results of CPE. The evaluation approach of CPE uses a rating system to classify each major treatment process as Type 1 , Type 2 , or Type 3 . The methodology to determine whether a unit process is classified as which type is based on the results of the measured capability and the instantaneous operating flow rate for a specific unit process. A unit process would be rated Type 1 if its operated capability exceeds the peak instantaneous operating flow rate; Type 2 if its measured capability is $80-100 \%$ of the peak flow; or Type 3 if its projected capability is less than $80 \%$ of the peak flow. The performance problems associated with Type 1 plants are likely related to plant operation, maintenance, and/or administration which can be improved by technical assistance. However, the Type 2 plants need to provide the minor corrections for process improvement to meet the performance goal. For Type 3 facilities, major modifications are required to achieve the objectives of performance. After CPE evaluation, comprehensive technical assistance (CTA) is processed for facilities improvement in water treatment plant. The initial step in assessment of CTA applicability is to determine if improved performance is achievable by evaluating the capability of major unit processes. A CTA is typically recommended if unit processes are deficient in capability (e.g., Type 3), acceptable performance from each "barrier" may not be achievable; and the focus of follow-up efforts may have to include construction alternatives. Another important consideration with Type 3 facilities is the immediate need for public health protection regardless of the condition of the plant.

A case study of the Chen-Chin-Lake water treatment plant located in the Kaoping watershed was performed to demonstrate how the CPE technique can successfully establish the appropriate Type 3 implementation plans. The flow chart of standard operational procedures for reviewing a performance of water treatment plant whose source water quality exceeds the national limit is shown in Fig. 5. To enhance drinking water quality in Kaohsiung metro, both the appropriate sound source water protection program and innovative water purification facilities are to be implemented as follows.

1. Source water protection program. Kaopin River, which supplies around 650,000 cubic meters daily for 2,370,000 residents within Kaoshiung metro areas, is polluted by livestock wastewater from hog farms, domestic sewage, industrial wastewater, landfill leachout, and non-point source (NPS) pollutants from agriculture areas, accounting for $52.5,11.2,28.8,2.2$, and $5.3 \%$ with total of 23,187 kg of BOD per day, respectively (Lin et al. 2002). The average source water quality data are shown in Table 8 . The major water treatment plant in this area is the Chen-Chin-Lake water treatment plant. Although the average $\mathrm{NH}_{3}-\mathrm{N}$ levels shown in Table 8 are under $1 \mathrm{mg} / \mathrm{L}$, several unacceptable observations have been found. Besides, the unpleasant taste and odor of tap water caused by the high organic matter and ammonia nitrogen in source water are the major issues always complained about by the local residents.

Enhanced Stream Water Quality Model (QUAL2E) developed by the US EPA was selected as a water quality-planning tool to assess the water quality based on its carrying capacity. It can simulate up to 15 water quality constituents including BOD, nutrients, DO, temp, algae as chlorophyll A, and total coliforms. QUAL2E can operate as a steady-state model which can be used to estimate the impact of waste loads (magnitude, quality, and location) on stream water quality. The constants used in the QUAL2E model were obtained from our previous study (Chiang et al. 2001).

The estimated carrying capacities of $\mathrm{BOD}, \mathrm{NH}_{3}-\mathrm{N}$, and $\mathrm{TP}$ are

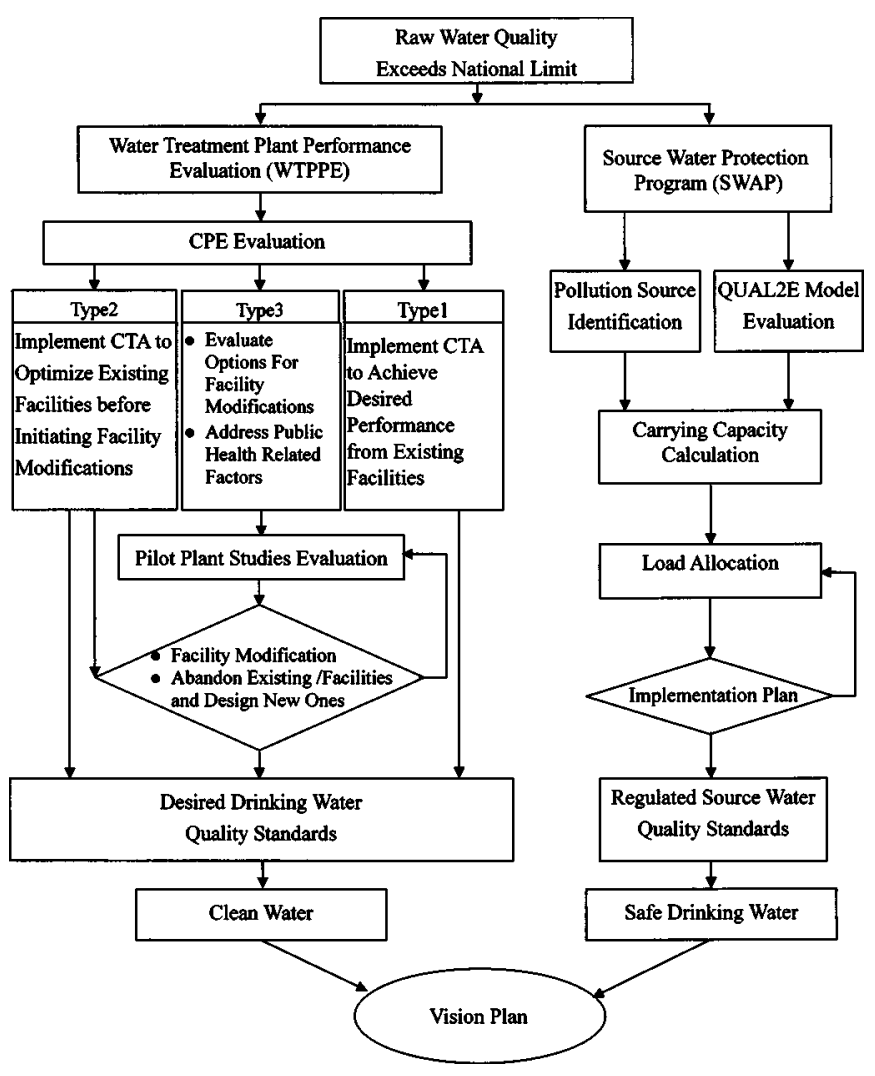

Fig. 5. Standard operational procedures for reviewing and/or approving a water treatment plant whose source water quality exceeds the national limit

$27,700,4,200$, and $600 \mathrm{~kg}$ per day. Daily total coliforms carrying capacity is found to be $4.8 \times 10^{15} \mathrm{CFU}$. The current BOD, $\mathrm{NH}_{3}$ -N, TP, and total coliform loadings are about 2.7, 9.4, 8.5, and 7.3 times higher than the calculated carrying capacities, respectively. To protect public health and improve the river water quality, the river pollution control management plans are proposed as follows: (a) hog ban in the whole Kaoping River basin; (b) sewer system construction to achieve $30 \%$ of population served area within 10 years; (c) removal of 10 riverbank landfills; and (d)

Table 8. Average Water Quality Data of the Chen-Chin-Lake Water Treatment Plant from 2000 to 2003

\begin{tabular}{lcc}
\hline Water quality parameters & Source water & Finish water \\
\hline Turbidity $(\mathrm{NTU})$ & $18.1( \pm 13.2)$ & $0.42( \pm 0.15)$ \\
Bicarbonate $(\mathrm{mg} / \mathrm{L})$ & $157( \pm 24)$ & $140( \pm 27)$ \\
$\mathrm{NH}_{3}-\mathrm{N}(\mathrm{mg} / \mathrm{L})$ & $0.21( \pm 0.18)$ & $0.06( \pm 0.01)$ \\
$\mathrm{TDS}(\mathrm{mg} / \mathrm{L})$ & $334( \pm 64)$ & $334( \pm 64)$ \\
Total hardness $(\mathrm{mg} / \mathrm{L})$ & $223( \pm 40)$ & $222( \pm 42)$ \\
Conductivity $(\mathrm{mmho} / \mathrm{cm})$ & $476( \pm 94)$ & $476( \pm 116)$ \\
Chloride $(\mathrm{mg} / \mathrm{L})$ & $9.4( \pm 4.9)$ & $14.1( \pm 6.9)$ \\
Nitrate $(\mathrm{mg} / \mathrm{L})$ & $1.08( \pm 0.35)$ & $1.01( \pm 0.31)$ \\
Fluoride $(\mathrm{mg} / \mathrm{L})$ & $0.15( \pm 0.04)$ & $0.15( \pm 0.05)$ \\
Sulfate $(\mathrm{mg} / \mathrm{L})$ & $81.5( \pm 17.1)$ & $96.6( \pm 16.5)$ \\
TOC $(\mathrm{mg} / \mathrm{L})$ & $9.4( \pm 4)$ & - \\
COD $(\mathrm{mg} / \mathrm{L})$ & $2.5( \pm 1)$ & - \\
Total coliforms $(\mathrm{CFU} / 100 \mathrm{~mL})$ & $2.7 \times 10^{3}\left( \pm 1.0 \times 10^{3}\right)$ & $<1$ \\
Total counts $(\mathrm{CFU} / 100 \mathrm{~mL})$ & $2.0 \times 10^{4}\left( \pm 4.0 \times 10^{4}\right)$ & $2( \pm 8)$ \\
\hline Note: TOC $=$ tot $0 t g a \mathrm{cat}$ &
\end{tabular}

Note: $\mathrm{TOC}=$ total organic carbon; and $\mathrm{COD}=$ chemical oxygen demand. 
Table 9. Simulated Loading after the Implementation of each Proposed Plan

\begin{tabular}{|c|c|c|c|c|c|c|c|c|c|}
\hline \multirow[b]{2}{*}{ Scenario } & \multirow[b]{2}{*}{ Measure } & \multicolumn{4}{|c|}{ Reduced loading } & \multicolumn{4}{|c|}{ Remaining loading } \\
\hline & & $\begin{array}{c}\text { BOD } \\
\text { (kg/day) }\end{array}$ & $\begin{array}{l}\mathrm{NH}_{3}-\mathrm{N} \\
(\mathrm{kg} / \text { day })\end{array}$ & $\begin{array}{c}\text { TP } \\
(\mathrm{kg} / \text { day })\end{array}$ & $\begin{array}{c}\text { Total } \\
\text { coliforms } \\
\text { (CFU/day) }\end{array}$ & $\begin{array}{c}\text { BOD } \\
\text { (kg/day) }\end{array}$ & $\begin{array}{l}\mathrm{NH} 3-\mathrm{N} \\
\text { (kg/day) }\end{array}$ & $\begin{array}{c}\mathrm{TP} \\
(\mathrm{kg} / \text { day })\end{array}$ & $\begin{array}{c}\text { Total } \\
\text { coliforms } \\
\text { (CFU/day) }\end{array}$ \\
\hline 1 & $\begin{array}{l}\text { Hog ban in the upper catchment to } \\
\text { reduce } 1 / 2 \text { hogs }\end{array}$ & 6,000 & 1,800 & 500 & $1.40 E+15$ & 68,700 & 37,600 & 4,600 & $3.40 E+16$ \\
\hline 2 & Hog ban in the whole basin & 37,800 & 17,300 & 2,800 & $1.57 E+16$ & 36,900 & 22,100 & 2,300 & $1.97 E+16$ \\
\hline 3 & $\begin{array}{l}\text { Construction of sewer system } \\
\text { ( } 20 \% \text { of connection in } 10 \text { years) }\end{array}$ & 3,900 & 50 & - & $6.70 E+15$ & 70,800 & 39,350 & - & $2.87 E+16$ \\
\hline 4 & $\begin{array}{l}\text { Sewer system construction } \\
\text { ( } 30 \% \text { of connection in } 10 \text { years) }\end{array}$ & 5,900 & 100 & - & $7.90 E+15$ & 68,800 & 39,300 & - & $2.75 E+16$ \\
\hline 5 & Removal of riverbank landfills & 2,800 & 800 & 80 & - & 71,900 & 38,600 & 5,020 & - \\
\hline 6 & $\begin{array}{l}\text { Reduction of industrial wastewater } \\
\text { discharge }\end{array}$ & 1,500 & - & - & - & 73,200 & - & - & - \\
\hline 7 & Scenarios $2+4+5+6$ & 48,000 & 18,200 & 3,600 & $2.36 E+16$ & $\begin{array}{c}26,700 \\
<27,700 \\
\text { (carrying } \\
\text { capacity) }\end{array}$ & $\begin{array}{c}21,200 \\
>4,200 \\
\text { (carrying } \\
\text { capacity) }\end{array}$ & $\begin{array}{c}1,500 \\
>600 \\
\text { (carrying } \\
\text { capacity) }\end{array}$ & $\begin{array}{c}1.18 E+16 \\
>4.81 E+15 \\
(\text { carrying } \\
\text { capacity) }\end{array}$ \\
\hline
\end{tabular}

Table 10. Comparisons of Finish Water Quality for Different Processes at the Pilot Plant in the Chen-Chin-Lake Water Treatment Plant

\begin{tabular}{|c|c|c|c|c|}
\hline \multirow[b]{2}{*}{ Water quality parameters } & \multirow[b]{2}{*}{ Source water } & $\begin{array}{c}\text { Process }^{\mathrm{a}}(\mathrm{I}) \\
\mathrm{O} \rightarrow \mathrm{C} \rightarrow \mathrm{S} \rightarrow \mathrm{F} \rightarrow \mathrm{O} \rightarrow \mathrm{G}\end{array}$ & $\begin{array}{c}\text { Process }^{\mathrm{a}} \text { (II) } \\
\mathrm{O} \rightarrow \mathrm{C} \rightarrow \mathrm{S} \rightarrow \mathrm{F} \rightarrow \mathrm{P} \rightarrow \mathrm{O} \rightarrow \mathrm{G}\end{array}$ & $\begin{array}{c}\text { Process }^{\mathrm{a}} \text { (III) } \\
\mathrm{O} \rightarrow \mathrm{C} \rightarrow \mathrm{S} \rightarrow \mathrm{F} \rightarrow \mathrm{O} \rightarrow \mathrm{G} \rightarrow \mathrm{N}\end{array}$ \\
\hline & & \multicolumn{3}{|c|}{ Finish water } \\
\hline Turbidity (NTU) & $\mathrm{NA}^{\mathrm{b}}$ & 0.20 & 0.07 & 0.03 \\
\hline NPDOC (mg/L) & 1.10 & 0.90 & 0.29 & 0.17 \\
\hline AOC $(\mu \mathrm{g}$ acetate-C eq/L) & NA & 25 & 13 & 4 \\
\hline Total Hardness (mg/L) & 238 & 230 & 109 & 18 \\
\hline TTHM $(\mu \mathrm{g} / \mathrm{L})$ & NA & 8.4 & 0.7 & 0.3 \\
\hline TTHMFP $(\mu \mathrm{g} / \mathrm{L})$ & 79.1 & 31.4 & $\mathrm{NA}^{\mathrm{b}}$ & $\mathrm{NA}^{\mathrm{b}}$ \\
\hline
\end{tabular}

${ }^{\mathrm{a}} \mathrm{C}=$ coagulation basin; $\mathrm{S}=$ sedimentation tank; $\mathrm{F}=$ rapid filtration basin; $\mathrm{G}=\mathrm{GAC}$ column; $\mathrm{O}=$ ozonation reactor; $\mathrm{P}=$ pellet softening bed; $\mathrm{N}$ $=$ nanofiltration.

${ }^{\mathrm{b}}$ Not available.

Table 11. Overall Performance Evaluation of the Selected Processes from the Aspect of Engineering, Environment, and Economy

\begin{tabular}{|c|c|c|c|c|c|c|c|c|c|}
\hline & \multicolumn{3}{|c|}{ Engineering } & \multicolumn{3}{|c|}{ Environment } & \multicolumn{2}{|c|}{ Economics } & \multirow{2}{*}{$\begin{array}{l}\text { Operation and } \\
\text { maintenance } \\
\text { cost }\end{array}$} \\
\hline & Process $^{\mathrm{a}}$ & Efficiency & Flexibility & Reliability & $\begin{array}{c}\text { Energy } \\
\text { consumption }\end{array}$ & $\begin{array}{l}\text { Environmental } \\
\text { impact }\end{array}$ & $\begin{array}{l}\text { Water } \\
\text { quality }\end{array}$ & $\begin{array}{l}\text { Installation } \\
\text { cost }\end{array}$ & \\
\hline (I) & $\mathrm{O} \rightarrow \mathrm{C} \rightarrow \mathrm{S} \rightarrow \mathrm{F} \rightarrow \mathrm{O} \rightarrow \mathrm{G}$ & Medium & Low & Medium & Low & Low & Good & Low & Low \\
\hline (III) & $\begin{aligned} \mathrm{O} \rightarrow \mathrm{C} \rightarrow \underset{\mathrm{S}}{\rightarrow} \rightarrow \mathrm{F} & \rightarrow \mathrm{P} \rightarrow \mathrm{O}\end{aligned}$ & High & Medium & High & Medium & Medium & Good & High & Medium \\
\hline (III) & 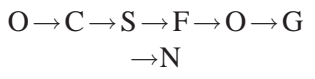 & High & High & High & High & Medium & Excellent & High & High \\
\hline
\end{tabular}


reduction of the industrial wastewater discharge. Reduced and/or remaining pollutants loading after the implementation of each proposed plan are shown in Table 9. With these implementation plans, it is expected that approximately $48,000 \mathrm{~kg}$ of daily BOD loading can be reduced, and the remaining BOD loading $(26,700 \mathrm{mg} /$ day $)$ is lower than the $27,700 \mathrm{mg}$ per day BOD carrying capacity. However, $\mathrm{NH}_{3}-\mathrm{N}$, TP, and total coliforms loads are still far beyond the calculated carrying capacities.

2. Water treatment plant performance evaluation. Since the source water quality cannot be upgraded within a limited time, the $\mathrm{CPE}$ technique was also performed to evaluate the performance of the existing facilities in the Chen-Chin-Lake water treatment plant. After the on-site visit, it was observed that performances of the flotation and the coagulation-sedimentation tanks are poor and floc-forming condition is not satisfactory. Additionally, high level of $\mathrm{NH}_{3}-\mathrm{N}$ has led to the overdose of pre-chlorination. In order to overcome these problems, pilot plant studies on process modification of the Chen-Chin-Lake water treatment plant were performed. Tables 10 and 11 present the overall performance evaluation of the selected processes from the aspect of finish water quality, engineering, environment and economy.

Among the three test processes of the pilot plants, process (III) exhibits the best performance in terms of high efficiency, flexibility, reliability, and excellent water quality. Therefore, the plan to introduce advanced water treatment processes in Chen-Chin-Lake water treatment plant was chosen as process (III), i.e., preozonation, coagulation, sedimentation, filtration, postozonation, GAC column, and nanofiltration. With these suggested treatment processes, it is expected: (a) to reduce the hardness from 240 to $150 \mathrm{mg} / \mathrm{L}$; (b) to replace pre-chlorination and postchlorination with ozonation; (c) to remove taste and odor by biological activated carbon filtration process. After completing the upgrading project, the water can meet the drinking water quality standard.

\section{Conclusions and Recommendations}

Source water quality criteria and standards from Taiwan and other countries were reviewed in this investigation. Chemical and bacterial water quality criteria, supplemented with a limited number of biological water quality criteria, are the principal indicators of water quality to be established by the developed nations. But, these comprehensive water quality indicators are not yet used and implemented regularly. This study suggests that Taiwan source water quality standards for total coliforms, TOC, and COD be revised in the future.

To achieve the long-term goal of improving water quality, it is recommended that stricter water quality standards in Taiwan be enforced gradually and divided into two execution phases. A uniform single standard should be adopted in Phase I, which can also be divided into two stages as shown in Table 7 . The regulated parameters should include representative parameters such as toxic substances, chemical and biological water quality indicators. The water treatment plant with an unacceptable source water quality needs to propose a source water protection program and/or seek on alternative source. Meanwhile, the CPE method is also introduced to find out the performance limiting factors and make improvement and modification of the existing facilities in the water treatment plant.

After Phase I objectives of source water protection are accomplished, various source water quality standards can be established and executed. In Phase II, additional regulated parameters will be added. Minimum treatment processes required for various source water quality will be defined. Applicable water pollution regulations for abating source water contamination will be enforced. All these activities should result in a much improved drinking water quality.

\section{Acknowledgments}

This research is supported by grants from the Toxic Material Management Bureau and Water Protection Bureau of Taiwan EPA. Special thanks are extended to experts from the Taiwan water supply industry and professors from various universities for their valuable input.

\section{References}

ANZECC. (2000). "Australian and New Zealand Guidelines for Fresh and Marine Waters, National Water Quality 2000." National Water Quality Management Strategy Paper No. 4, Australian and New Zealand Environment and Conservation Council.

Chang, E. E., Chiang, P. C., Chao, S. H., and Chuang, C. L. (1999). "Development and implementation of source water quality standards in Taiwan, ROC." Chemosphere, 39(8), 1317-1332.

Chang, E. E., Chiang, P. C., and Lin, T. F. (1998). "Development of surrogate organic contaminants parameters source water quality standards in Taiwan, ROC." Chemosphere, 37, 593-606.

Chiang, P. C., Chang, E. E., Ko, Y. W., and Lou, J. C. (1997). "Balancing disinfection efficiency and THM formation during chlorination: Theoretical considerations." Can. J. Chem. Eng., 75, 892-898.

Chiang, P. C., Kao, C. M., Huang, S. S., Lin, T. F., Yan, Y. L., and Chang, E. E. (2001). "Water quality management in the Kaoping river basin, Taiwan." WEF Conference, JWEF, July 27-28, Tokyo.

Code of Maryland Regulation, Title 26, Dept. of the Environment, Subtitle 08 Water Pollution, Chapter 2-Water Quality.

Copper, A. L., and Young, J. C. (1984). Chemical non-specific organic analysis, Vol. 3, Academic, New York.

Dobbs, R. A., Wise, R. H., and Dean, R. B. (1972). "The use of ultraviolet absorbance for monitoring the total organic carbon of water and wastewater." Water Res., 6, 1173-1180.

EC. (1975). "Council directives: Concerning the quality required of surface water intended for the abstraction of drinking water in the member states." 75/440 EEC, Official Journal of the European Communities.

Edzwald, J. K., Becker, W. C., and Wattier, K. L. (1985). "Surrogate parameters for monitoring organic matter and THM precursors." $J$. Am. Water Works Assoc., 77, 122-134.

Kikuchi, S. (1975). Quality management, Japan's Water Works Yearbook.

Lin, T. H., Liu, H. W., and Yeh, T. Y. (2002). "Pollution reduction strategies within source water protection zones-Kaopin rover case study." The 8th Int. Conf. on Drinking Water Quality Management and Treatment Technology, Kaohsiung, Taiwan.

MELP. (1995). "Working criteria for water quality-Canada, water quality branch 1995." Ministry of Environment, Lands and Parks, Environmental Protection Dept.

NAS. (1972). National Academy of engineering water quality criteria 1972, National Academy of Sciences, Washington, D.C.

Sato, K. (2002). "Round table discussion paper." The 8th Int. Conf. on Drinking Water Quality Management and Treatment Technology, Kaohsiung, Taiwan.

Singer, P. C., Obolensky, A., and Greiner, A. (1995). "DBPs in chlorinated North Carolina drinking waters." J. Am. Water Works Assoc., 84, 83-95. 
Tien, C. T. (2002). "Round table discussion paper." The 8th Int. Conf. on Drinking Water Quality Management and Treatment Technology, Kaohsiung, Taiwan.

U.S. Environmental Protection Agency (USEPA). (1998). "Handbook: Optimizing water treatment plant performance using the composite correction program." 1998 Ed., United States Environmental Protec- tion Agency, EPA/625/6-91/027, Technical Support Center, Office of Water, Cincinnati.

Van der Leeden, F., Troise, F. L., and Todd, D. K. (1990). The water encyclopedia, 2nd Ed., Lewis, Boca Raton, Fla.

Wilson, A. L. (1959). "Determination of fulvic acids in water." J. Appl. Chem., 9, 501-512. 